\title{
Contributions of Solid Wastes Disposal Practice to Malaria Prevalence in Ilorin, Nigeria
}

\author{
O. A. Mokuolu ${ }^{*}$, A. O. Coker², M. K. C. Sridhar ${ }^{3}$ \\ ${ }^{1}$ Department of Water Resources and Environmental Engineering, University of Ilorin, Ilorin, Kwara State, Nigeria. \\ ${ }^{2}$ Civil Engineering Department, University of Ibadan, Ibadan, Oyo State, Nigeria. \\ ${ }^{3}$ Department of Environmental Health Sciences, University of Ibadan, Ibadan, Oyo State, Nigeria.
}

\begin{abstract}
Environmental control has been part of global reduction for malaria prevalence. However currently, its consideration for malaria control is very little. A community based study was conducted for malaria prevalence in Okelele, Ilorin East Local Government Area of Kwara State, Nigeria. A total of 200 households were studied which comprise of 501 children, age $\geqslant 14$ years, 241 females, and 260 males. Data was recorded on the study profoma and entered into the computer using statistical software package. The results indicated that $29.9 \%$ were found to be positive with use of RDT, open drainage, stagnation of water in drain, solid waste in drain and presence of weed were found to be significant factors to malaria increase at p-value $<0.05$. Integrated Solid Wastes Management (ISWM) and community cooperation are being proposed in this study.
\end{abstract}

KEYWORDS: Malaria, solid waste, open drainage, RDT, environment.

[Received September 30 2015; Revised March 82016 \& April 10 2016; Accepted April 16 2016]

\section{INTRODUCTION}

Malaria disease is transmitted to man by the bites from certain species of infected female anopheline mosquito (WHO, 2006)). It is a serious problem in Africa where one in every five (20\%) childhood deaths is due to the effects of the disease (Sachs and Malaney, 2002). There were an estimated 198 million episodes of malaria globally in 2013, of which approximately $90 \%$, or 178 million cases, were in the African Region. There were an estimated 584000 malaria deaths in 2013 , approximately $78 \%$ of malaria deaths globally were of children under 5 years of age (WHO, 2014).

Mosquitoes may breed anywhere that standing water is available. Natural and man-made habitats include temporary flooded areas, tidal or fresh water wetlands, lakes, ponds, and rivers, municipal sewage or wastewater treatment plants, flooded basements of abandoned buildings, etc. Examples of smaller man-made potential breeding habitats include household articles and discarded trash such as tyres, drums, pails, garbage cans, plant pots, swimming pools, bottles, discarded automobiles and household appliances (Bourne, 2003). Larval control measures are intended to reduce malaria transmission indirectly by reducing the vector population density near human habitations. As the larvae are exclusively aquatic, their distribution is determined by the locations of suitable water bodies (Walker and Lynch, 2007). One advantage of targeting larvae is that they cannot escape from their breeding sites until the adult stage and, unlike adult mosquitoes. Some of the main causes of malaria in the Sub Sahara African region are: Poor sanitation and indiscriminate dumping of refuse (Kobina et al, 2010; Tchobanoglous et al., *Corresponding author's e-mail address: olubunmimokuolu@yahoo.com
1977). Poorly managed waste often ends up in ponds, reservoirs, or drainage systems. The refuse often blocks drainage channels, resulting in the ponding of water: these surface waters are often polluted with organic waste, becoming breeding sites for mosquito larvae.

Solid waste comprises all the waste arising from human and animal activities that are normally solid and are discarded as useless or unwanted disposal. Wastes can be generated by natural phenomena such as wind, erosion, precipitation, volcanic eruptions, flooding of river banks, atmospheric fallouts, among others and by human activities including domestic; commercial, industrial and agricultural practices (Adeoye et al., 2012). Poor solid waste management will result in an unpleasant and often unsafe environment to live or work in.

In urban areas, refuse often ends up in drainage systems, creating drainage problems while solid waste that accumulates in the system is often contaminated, and is a health risk to those who live within its proximity and those that handles it. The health issues related to drainage water management can be grouped in three categories: water related vector-borne diseases; faecal/orally transmitted diseases; and chronic health issues related to exposure to residues of agrochemicals (Celestino et al., 2012). Ajao et al., (2011) investigated the relationship between mortality rate and household sanitation among the states in Nigeria. They found out that bad refuse disposal contribute more to "crude death rate" in the states investigated including Kwara state; in a similar study by Sridhar et al., (2007) developed indigenous technologies under "Integrated Waste Recycling" scheme in order to make Akure

doi: http://dx.doi.org/10.4314/njtd.v13i1.1 
cleaner. Unhygienic or improper disposal of solid waste, apart from being aesthetically displeasing, constitute health risks to human beings. Satisfactory method of refuse disposal is constituted by the use of Government bins, bins collected by private agencies, while unsatisfactory refuse disposal system is reflected in the use of unauthorized refuse dumps. This study examines the contributions of solid waste disposal practices to malaria prevalence in a Nigerian peri-urban community.

\section{Methodology}

\section{A. Study Location}

The study was conducted in Okelele in Ilorin East local Government area of Kwara State. Okelele has a population of 36,191 based on 2006 census (National Population Commission) and forecasting 47,221 by 2015 (Agunwamba, 2008). It lies between longitude $04^{\circ} 32^{\prime}$ and latitude $08^{\circ} 26^{\prime}$ with estimated land area of $1.5 \mathrm{~km}^{2}$. The relief flanking the flood plains around Okelele is between $290 \mathrm{~m}$ and $305 \mathrm{~m}$ above the sea level. (Personal Communication with the Surveyor General, Kwara State Government, 2012 and confirmed through GIS).

\section{B. Sampling Procedure}

A preliminary survey of the study site was conducted identifying the presence of environmental factors that could contribute to the malaria burden of the area (morbidity and mortality) thereafter; a 3-stage random sampling technique (multistage sampling technique) was used in selecting respondents for the study.

Stage1: Okelele area was divided into five zones with the assistance of local guide. Each of the zone was named after the most prominent compound within it. Zone 1 Lowin, Zone 2 Amuyankan, Zone 3 Omoboriowo, Zone 4 Jagun and Zone 5 Babaladifa.

Stage 2: Forty (40) households, each from the 5 zones, were randomly selected by balloting.

Stage 3: In each selected household, two or three children aged less than 14 years old were randomly selected through balloting per household.

\section{Inclusion and Exclusion Criteria}

The main criterion for inclusion on the study was that the household must have at least 2 children below that age of 14 years on the day of the survey. Household with one or no children below the age of 14 years were excluded from the study.

\section{Instrument of Data Collection}

Validated structured questionnaire was used for data collection in the study. The questionnaire administered on daily basis were reviewed and edited to ensure completeness and consistency. The reliability of the questionnaire was tested using the Alpha Cronbach's reliability test. The questionnaire was developed to obtain information on use of malaria preventive measures, children data, their surrounding among others. The parent/ guardian of each child were the respondents. Malaria prevalence was determined in children under 14years; representing the most vulnerable age group to the disease (Oresanya et al., 2008, Mokuolu et al., 2009,
Nkwocha et al., 2011). This was to eliminate the possible bias from a type-2 error that may arise from under representation of adult subjects using the malaria Rapid Diagnostic Test kit (RDT), Paracheck. This test kit is based on the identification of parasite Histidine rich protein II (HRP-2) that is present on the parasite cell wall.

\section{E. Contributions of solid waste}

The open drainages were examined for the type of solid waste content.

\section{F. Data Management and analysis}

Survey data collected using questionnaire were checked on the field for completeness and consistencies. Data entry clerk was given adequate training that enabled her to identify problems with data quality prior to the entry of the questionnaire into the database. The data was thereafter entered into computer using the SPSS 17.0 software package. The data entered were checked for errors and cleaned as appropriate before computation and data analysis. Descriptive statistics were generated from the data set and results presented in tables, charts and figurers. The association between two categorical variables was tested using the Chi-Square test. Association between continuous variables and an outcome variable was tested using the student t-test where the assumptions are met; otherwise a non-parametric test was applied.

A number of the variables generated were also fed into the development of the mathematical model for determining the relationship between malaria prevalence (RDT) and environmental factors / non environmental factor using multiple regression models. All the analysis was carried out at $5 \%$ level of significance.

\section{G. Ethical considerations}

The institutional ethical clearance was granted by the University of Ilorin Teaching Hospital Ethical Review Committee before the commencement of the field work. In addition, permission was obtained from the district authorities and community leaders. Individual interviews and tests for baseline data were only started after the purpose of the study had been clearly explained to the participants and informed verbal consent obtained. Participation was made voluntary and no form of coercion was adopted. There was no undue influence on the participants. Participants were ensured of confidentiality of all information obtained from them and respondents' names were not written on the questionnaire in order to ensure anonymity.

\section{RESULTS AND DISCUSSION}

A total of 200 households were studied comprising 501 children, 241(48.1\%) females and 260(51.9\%) males (Figure.1). The average number of children $\geqslant 14$ years was 4 per household. The ages of the children ranged from 8 months to 14years, with an average of 6.8. The weight ranged from $5.5 \mathrm{~kg}$ to $53.0 \mathrm{~kg}$ with an average weight of $19.13 \mathrm{~kg}$ as shown on Table 1. A total of $29.9 \%$ of the Children tested with RDT were found positive as indicated in Figure.2. From the 200 households studied, 196(99.0\%) had open drainage in their surroundings, the following predictors: Solid Wastes in Drains 
(SWD), Stagnation of Wastewater in Drains (STWD), Presence of Open Drains (POD), and Presence Of Weeds (POW) having p-value $<0.05$ level of significance contributes significantly as independent variables in explaining the dependent variable, malaria prevalence (RDT) as shown on Table 2.

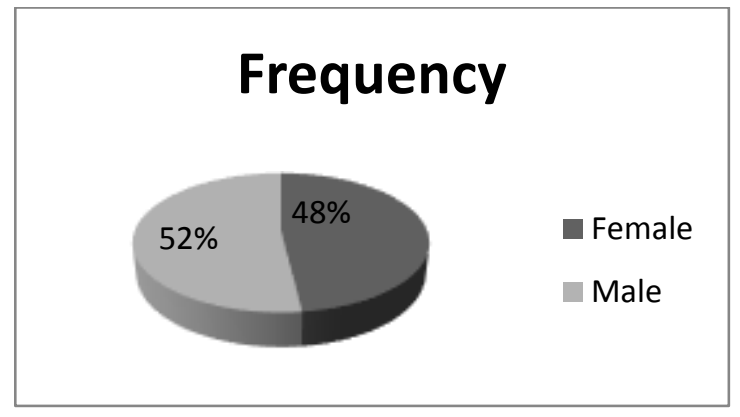

Figure 1 Characteristics of study population.

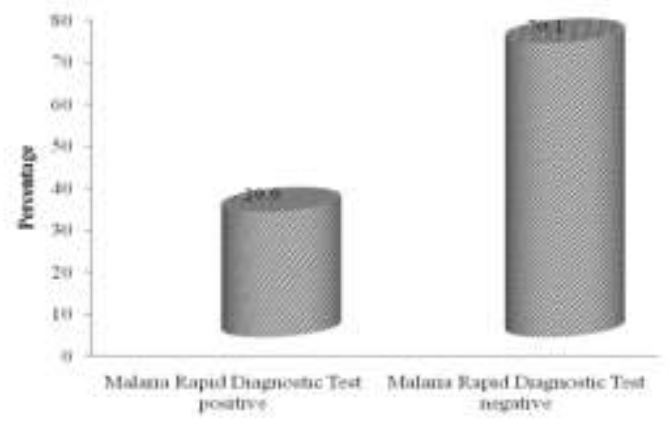

Figure 2 Result of the RDT.

Table 2: Modelling household surroundings features as predictors of malaria prevalence (RDT positivity)

\begin{tabular}{ccccc}
\hline Variables & $\begin{array}{c}\mathrm{R} \\
\text { square }\end{array}$ & $\begin{array}{c}\alpha \\
\text { (coefficient) }\end{array}$ & $\beta$ & F/t (p Value) \\
\hline A & & & & \\
Model & 0.5478 & & & $25.245(0.000)$ \\
POD & & -19.7046 & -0.2569 & $4.67(0.000)$ \\
SWD & & -14.5096 & -0.1302 & $2.54(0.012)$ \\
STWD & & 31.5975 & 0.4292 & $7.85(0.000)$ \\
POW & & -27.6002 & -0.3423 & $6.35(0.000)$ \\
Constant & & 86.9497 & & \\
\hline
\end{tabular}

A. Contributions of solid wastes

Solid wastes in the open drainages were found to contain mainly nylons, leaves (used for eating certain types of local solid foods), rags, papers, empty cans, broken local pot, and human excreta. The solid wastes were observed to be the main reason for waste water stagnation in the drains as shown in plate 1 . Plate 2 is presented to show typical drainage in the study area.

\section{B. Discussion}

The result shows open drainage to be a significant factor to malaria prevalence in the study area. Castro et al, 2009 conducted a similar study in Dares salaam, Tanzania.

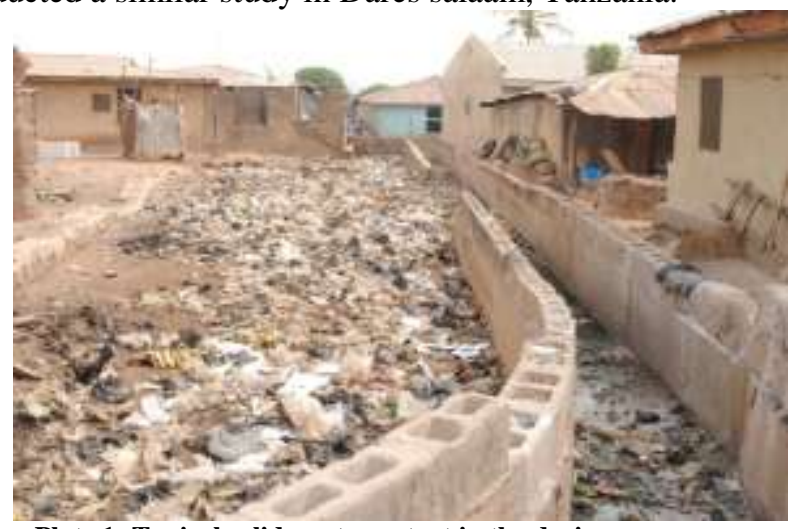

Plate 1: Typical solid waste content in the drain.

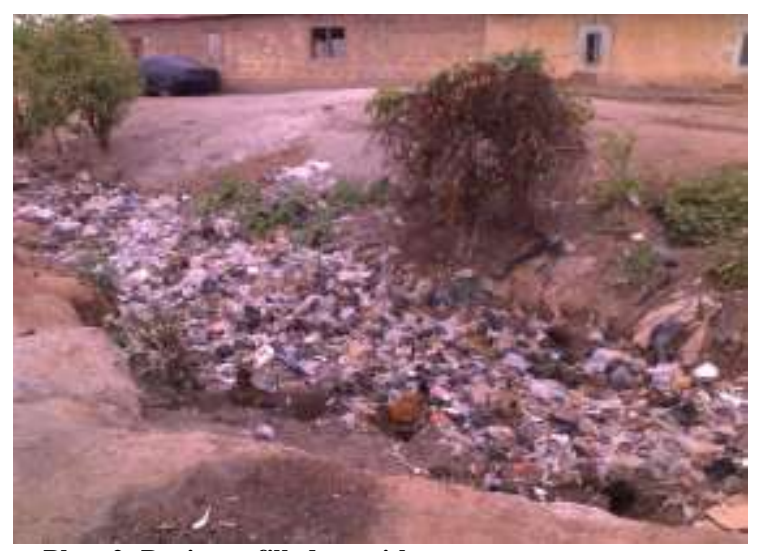

Plate 2: Drainage filled up with waste.

They concluded that Environmental management as part of an integrated vector management framework for malaria control is expected to reduce malaria transmission. Communal wastes blocking the open drainages because of poor sanitation of the site contribute largely to the high prevalence. Typical per capita solid waste generation rates for residential areas in Ilorin is $0.22 \mathrm{~kg}$ per capital per day (Aremu et al., 2012). Agunwamba et al., (1998) recorded $0.53 \mathrm{~kg}$ per capita per day for Onitsha. The Okelele community does not have good waste management practice; wastes are being dumped indiscriminately in the open drainages and other open spaces around the community with occasional open burning. The uncontrolled discharge of waste must be discouraged, and the displaced wastes in drainages and open places have to be collected.

Prevention of waste accumulation was proposed by Coker and Sridhar (2010) as a means of reducing fire risk and biological hazards however, Integrated Solid Waste Management (ISWM) is being proposed in this study. ISWM is a comprehensive waste prevention, recycling, composting, and disposal program. An effective ISWM system considers how to prevent, recycle, and manage solid waste in ways that most effectively protect human health and the environment. ISWM involves evaluating local needs and conditions, and 
then selecting and combining the most appropriate waste management activities for those conditions. The major ISWM activities are waste prevention, recycling and composting, and combustion and disposal in properly designed, constructed, and managed landfills or monitored disposal sites. Each of these activities requires careful planning, financing, collection, and transport (USEPA, 2002).

The Okelele Community has a rural setting and may require community cooperation and Government interventions for alleviation. Prioritizing willingness of community participation in environmental sanitation was expressed by Oluwole (2012). Government plays an important role in developing and enforcing waste management standards, providing funding, and managing day-to-day operations of solid waste management activities. Agunwamba, (1998) reported that the cores of the problems of solid waste management in Nigeria are the absence of adequate policies, enabling legislation, an environmentally stimulated and enlightened public.

\section{CONCLUSION AND RECOMMENDATIONS}

The study has demonstrated the contributions of solid wastes disposal practice to malaria prevalence in Okelele area of Ilorin. It also provided a parameter for designing proper waste management solution for the community. ISWM is proposed in this study with further communication with the community for cooperation and understanding of the issue at stake. Construction of public toilets is recommended as human excreta were found in the open drains.

\begin{tabular}{|c|c|c|c|c|}
\hline \multirow[t]{2}{*}{ Children's characteristics } & \multicolumn{2}{|c|}{ Malaria prevalence (RDT positivity) } & \multirow[t]{2}{*}{ Total } & \multirow[t]{2}{*}{$\chi^{2}$, Df, (p value) } \\
\hline & Negative $(\%)$ & Positive (\%) & & \\
\hline \multicolumn{5}{|l|}{ Sex } \\
\hline Male & $192(54.5)$ & $68(45.6)$ & 260 & $3.328,1,(0.068)$ \\
\hline Female & $160(45.5)$ & $81(54.4)$ & 241 & \\
\hline Total & 352 & 149 & 501 & \\
\hline \multicolumn{5}{|l|}{ Age category (months) } \\
\hline$\leq 12$ & $27(7.7)$ & $8(5.4)$ & 35 & $5.554,3,(0.135)$ \\
\hline$>12-59$ & $116(33.0)$ & $49(32.9)$ & 165 & \\
\hline$>59-118$ & $118(33.5)$ & $64(43.0)$ & 182 & \\
\hline$>118-168$ & $91(25.9)$ & $28(18.8)$ & 119 & \\
\hline Total & 352 & 149 & 501 & \\
\hline \multicolumn{5}{|l|}{ Use of mosquito's net } \\
\hline Yes & $41(11.6)$ & $15(10.1)$ & 56 & $7.745,1,(0.171)$ \\
\hline No & $311(88.4)$ & $134(89.9)$ & 445 & \\
\hline Total & 352 & 149 & 501 & \\
\hline
\end{tabular}

\section{REFERENCES}

Adeoye, P.A.; S. M. Dauda, J.J. Musa, S.E. Adebayo, and M.A. Sadeeq. (2012). Evaluation hnology in Environmental Sanitation, 2(1):17-22.

Agunwamba, J.C.; O.K. Ukpai, and I.C. Onyebuenyi. (1998). Solid Waste Management in Onitsha, Nigeria. Waste Management and Research. 16(1): 23-31.

Agunwamba, J.C. (2008). Water Engineering Systems. De-Adroit Innovation. Pp 19-26.

Ajao, I.O.; O.S. Obafemi, and T.O. Ewumi. (2011). Household sanitation and mortality rate in Nigeria: an expository analysis. Journal of Applied Sciences in Environmental Sanitation, 6(3): 333-342.

Aremu, S. A.; B. F. Sule, J. Downs, and R.J. Mihelci. (2012). Framework to determine the optimal spatial location and number of municipal solid waste bins in a developing world urban neighbourhood. American Society of Civil Engineers. 138(6): 645- 652.
Bourne, B. (2003). Health \& Management/ managing for West Nile virus infection/ Technique: collection and counting of mosquito larvae for West Nile virus control. Accessed on 10th May 2015 from http://wildlife1.wildlifeinformation. org/s/00Man/WNVOverviews/WNVIndTech/W.

Castro C. M.; A. Tsurata, S. Kanamori, K. Kennedy, and S. Mkude. (2009). Community based environmental management for malaria control: evidence from a small scale intervention in Dar-es-Salaam, Tanzania. Malaria Journal 8:57.

Celestino, L. J. L.; A.O. Mohammed, and L. Xiwu. (2012). Solid waste management and its Environmental impacts on human health in Juba Town - South Sudan. Scholarly Journals of Biotechnology. 1(2): 28-38.

Coker, A.O., and Sridhar, M.K.C. (2010). Controlling exposure to biological hazards. ICE Manual of health and safety in construction. Institution of Civil Engineers, 135-148. 
Kobina, O. A.; G.K. Nyarko, and A. M. Koomson. (2002). Malaria in the sub Saharan Africa. Revista VacciMonitor (Vacunología y Temas Afines), 11(4): 1-6.

Mokuolu, A. O.; C.O. Falade, A. O. Adeola, U.O. Henrietta, T.A. Olanrewaju, A.O. Tagbo, H.O. DadaAdegbola, O.A. Oguntayo, K.E. Samuel, H.H. Davidson, and V.C. Michael. (2009). Malaria at Parturition in Nigeria: Current Status and Delivery Outcome. Infectious Diseases in Obstetrics and Gynecology. Article ID 473971, 7.

Nkwocha, E. E.; R.O. Egejuru, E.C. Pat-Mbano, and R.F. Njoku-Tony. (2011). Proximity of municipal waste dumpsites to residential neighbourhoods and rate of hospitalization for malaria. International Journal of Advanced Biotechnology and Research. 2(1): 159-167.

Oluwole, D. (2012). Clapping with one hand: the case of urban environmental sanitation practices in Nigeria. Journal of Applied Technology in Environmental Sanitation, 2(4): 223228.

Oresanya, B. O.; H. Moshe, and T.S. Olayemi. (2008). Utilization of insecticide-treated nets by under-five children in Nigeria: Assessing progress towards the Abuja targets. Malaria Journal, 7:145.
Sachs J, and Malaney, P. (2002). The economic and social burden of malaria. Nature. 415:680-685.

SPSS, Inc. Statistical package for the social sciences version 17.0.

Sridhar M. K. C.; I.O. Olaseha, G. O. Adeoye, T. Tajudeen, and B.C. Ogunwolere. (2007). Sustainable Waste Management through Integrated Waste Recycling. The International Journal of Environment, Cultural, Economic and Social Sustainability, 3(3): 103-112.

Tchobanoglous, G.; T. Hilary, E. Rolf. (1977). Solid Wastes Engineering Principles and Management issues. Mcgraw-Hill Book Company, 7- 73.

United States Environmental Protection Agency, (USEPA) (2002). Solid Waste and Emergency Response. Accessed October 10th 2014, from www.epa.gov/globalwarming

Walker, K., and Lynch, M. (2007). Contributions of Anopheles larval control to malaria suppression in tropical Africa: review of achievements and potential. Medical and Veterinary Entomology. 21: 2-21.

WHO (2006). Malaria vector control and personal protection: report of a WHO study group.

WHO (2014): World Malaria Report. 